\title{
EFEKTIVITAS EKSTRAK BIJI PANGI (Pangium edule Reinw) TERHADAP MORTALITAS LARVA NYAMUK Anopheles
}

\author{
Viesta Sampe $^{1}$, Th. Watuguly ${ }^{2}$ \\ ${ }^{1}$ Alumni Program Studi Pendidikan Biologi \\ 2Dosen Program Studi Pendidikan Biologi \\ E-mail: viesta_sampe@yahoo.com
}

\begin{abstract}
Background: Eradication of mosquito nests in Maluku is still done by fogging and with other chemicals. But on the other hand can cause disease in the respiratory tract and environmental damage. Pangi seeds contain alkaloids and potentially saponin compounds as larvacide to kill mosquito larvae.

Method: The study design was using RAL (Completely Randomized Design) with 5 treatments ie K1 (control), K2 0,04\%, K3 0,08\%, K4 0,16\% and K5 0,23\% with each 25 larvae with 3 repetitions observed for 24 hours. One Way ANOVA Test Result and Probit LC50 Analysis were used to find out the extract of pangi seed which is effective in killing mosquitoes.

Result: One Way ANOVA test result obtained Fcount value is 467.063 with Sig value. 0.000 and probit analysis obtained 24 hours LC50 value of $0.053 \%$ means that the extract of pangi seed (Pangium edule Reinw.) Is effective against mortality of Anopheles mosquito larvae.

Conclusion: Seed extract (Pangium edule Reinw) effect on mortality of Anopheles mosquito larvae with LC50 extract value of Pangi (Pangium edule Reinw) in 24 hours was $0.053 \%$. Each concentration of pangi seed extract (Pangium edule Reinw) had an effect on mortality of Anopheles mosquito larvae within 24 hours of observation time. There was a correlation between various concentrations of Pangi (Pangium edule Reinw) with the mortality of Anopheles mosquito larvae with value $(p)=0.000$ and the relationship level was very strong with Pearson correlation value 0.891 .
\end{abstract}

Keywords: Effectiveness, Pangi Seed (Pangium edule Reinw.), Anopheles.

\begin{abstract}
Abstrak
Latar Belakang: Pemberantasan sarang nyamuk di Maluku masih dilakukan dengan cara fogging dan dengan bahan kimia lainnya. Namun disisi lain dapat menimbulkan penyakit pada saluran pernafasan dan kerusakan lingkungan. Biji pangi mengandung senyawa alkaloid dan saponin yang berpotensi sebagai larvasida untuk membunuh larva nyamuk.

Metode: Rancangan penelitian menggunakan RAL (Rancangan Acak Lengkap) dengan 5 perlakuan yaitu $\mathrm{K} 1$ (kontrol), K2 0,04\%, K3 0,08\%, K4 0,16\% dan K5 0,23\% dengan masing-masing 25 larva dengan 3 kali ulangan yang diamati selama 24 jam. Hasil Uji One Way ANOVA dan Analisis Probit $\mathrm{LC}_{50}$ digunakan untuk mengetahui ekstrak biji pangi yang efektif dalam membunuh nyamuk.

Hasil: Hasil uji One Way ANOVA diperoleh nilai $F_{\text {hitung }}$ adalah 467.063 dengan nilai Sig. 0,000 dan analisis probit diperoleh nilai LC 5024 jam sebesar $0,053 \%$ artinya ekstrak biji pangi (Pangium edule Reinw.) efektif terhadap mortalitas larva nyamuk Anopheles.

Kesimpulan: Ekstrak biji pangi (Pangium edule Reinw) berpengaruh terhadap mortalitas larva nyamuk Anopheles dengan nilai $\mathrm{LC}_{50}$ ekstrak biji pangi (Pangium edule Reinw) dalam 24 jam adalah 0,053\%. Setiap konsentrasi ekstrak biji pangi (Pangium edule Reinw) berpengaruh terhadap mortalitas larva nyamuk Anopheles dalam 24 jam waktu pengamatan. Terdapat hubungan antara berbagai konsentrasi biji pangi (Pangium edule Reinw) dengan mortalitas larva nyamuk Anopheles dengan nilai $(p)=0,000$ dan tingkat hubungannya sangat kuat dengan nilai pearson corellationnya 0,891 .
\end{abstract}

Kata kunci: Efektivitas, Biji Pangi (Pangium edule Reinw.), Anopheles. 


\section{PENDAHULUAN}

Penyebaran berbagai penyakit oleh nyamuk merupakan suatu masalah kesehatan yang sangat serius, salah satunya adalah penyakit malaria. Penyakit malaria adalah penyakit yang disebabkan oleh parasit dari marga Plasmodium yang ditularkan melalui gigitan nyamuk Anopheles. Penyakit tersebut juga dapat mempengaruhi angka kematian bayi, anak di bawah umur lima tahun serta ibu hamil. Kejadian Luar Biasa (KLB) sering terjadi di beberapa daerah akibat perubahan lingkungan dan perpindahan penduduk serta terbatasnya pelayanan kesehatan masyarakat sehingga menyebabkan kematian (Dinas Kesehatan Provinsi Maluku, 2012). Faktor kesehatan lingkungan fisik, kimia, biologis, dan sosial budaya sangat berpengaruh terhadap penyebaran penyakit malaria (Sanaky, 2014).

Provinsi Maluku merupakan daerah endemis penyakit malaria. Berdasarkan laporan Program Malaria Bidang P2B Dinas Kesehatan Provinsi Maluku tahun 2012 jumlah Angka Kesakitan API (Annual Paracite Incidence) tahun 2008 sebesar 12,3/1000 penduduk, tahun 2009 sebesar 7,0/1000 penduduk, tahun 2010 sebesar 10,4/1000 penduduk, pada tahun 2011 sebesar 9,2/1.000 penduduk, dan pada tahun 2012 sebesar 11,1/1000 penduduk. Beberapa faktor yang yang mempengaruhi Angka Kesakitan Penyakit Malaria di Maluku adalah kondisi fisik rumah, tempat perkembangbiakan nyamuk, penggunaan obat nyamuk semprot dan jarak puskesmas. Salah satu yang menjadi perhatian adalah kesehatan lingkungan dengan banyaknya tempat perindukan nyamuk di Maluku. Tempat perindukan nyamuk (Breeding sites) merupakan habitat penting bagi nyamuk yang merupakan vektor utama penyebab penyakit bagi manusia untuk berkembang biak. Tempat perindukan nyamuk (Breeding sites) Family Anophelidae berada di luar rumah pada bekas genangan air yang kotor misalnya pada kolam-kolam yang di lewati mobil, saluran air, daerah rawa, tempat bekas penebangan pohon sagu dan hutan mangrove (Pagaya dkk., 2005).

Pemberantasan sarang nyamuk di Maluku masih dilakukan dengan fogging dan dengan bahan kimia lainnya tetapi di sisi lain akibatnya menimbulkan penyakit lain yang seperti penyakit pada saluran pernafasan. selain itu penggunaannya secara terus-menerus dan berulang-ulang dapat menimbulkan pencemaran lingkungan karena mengandung bahan kimia yang sulit terdegradasi di alam, kematian berbagai jenis makhluk hidup dan resistensi terhadap vektor penyakit. Dewasa ini, kontrol terhadap populasi nyamuk vektor penyakit difokuskan pada stadium larva sehingga memutus rantai penularan penyakit oleh nyamuk. Keuntungannya adalah pada stadium ini larva nyamuk tidak dapat berpindah dari tempat pembiakannya sebelum mencapai stadium dewasa. Cara pengendalian vektor dengan memanfaatkan tanaman sebagai biopestisida merupakan salah satu alternatif pengendalian yang ramah lingkungan, mudah diaplikasikan dan tidak berbahaya bagi musuh alami dan serangga menguntungkan lainnya (Tennyson et al., 2012). Untuk itu salah satu allternatif yang baik untuk memberantas penyakit malaria adalah dengan memanfaatkan bahan alami yang mudah didapat dan ramah lingkungan salah satunya adalah tanaman pangi (Pangium edule Reinw.).

Pangi merupakan salah satu tumbuhan baik akar, batang, daun, buah dan biji memiliki banyak manfaat. Pangi adalah salah satu sumber daya alam hayati hutan Indonesia yang memiliki kandungan senyawa alami antimikroba. Pada daun, buah dan biji pangi memiliki kandungan senyawa kimia yang besifat racun dengan taraf konsentrasi tertentu. Hasil penelitian dari 16 jenis buah dan 46 jenis sayuran yang tumbuh di Serawak mempunyai kandungan protein sekitar 6-7\%. Salah satu diantara tanaman tersebut adalah tanaman pangi yang mempunyai potensi untuk digunakan lebih luas dalam kebutuhan sehari-hari maupun untuk diperdagangkan (Hoe and Siong, 2002). Biji pangi yang mengandung lemak jika difermentasi akan menghasilkan lemak siklik tidak jenuh yaitu asam hidrokarpat, khaulmograt dan goulat (Erni, 2006). Selain itu, biji pangi terkandung senyawa asam sianida, saponin, flavonoid, alkaloid, tanin dan polifenol (Warintek, 2006). Meyer dalam Heriyanto dan Subiandono (2008) 
menyatakan bahwa pangi juga dapat digunakan sebagai insektisida hayati. Zatzat toksik pada kandungan Biji pangi dimungkinkan dapat digunakan untuk membunuh beberapa hama serangga yang tidak menguntungkan bagi manusia.

\section{MATERI DAN METODE PENELITIAN Lokasi dan Waktu Penelitian}

Lokasi Penelitian ini dibagi atas 2 yaitu, untuk tahap ekstraksi biji pangi dilakukan di Laboratorium Biologi Dasar, Fakultas Keguruan dan IImu Pendidikan dan tahap penelitian dilakukan di Laboratorium Zoologi Fakultas MIPA, Universitas Pattimura, Ambon. Penelitian ini dilakukan pada mulai dari tanggal $22-31$ April 2016.

\section{Jenis Penelitian}

Jenis penelitian ini merupakan penelitian komparatif dan korelasional dengan menggunakan rancangan penelitian Rancangan Acak Lengkap (RAL) yaitu K1 sebagai kontrol, $\mathrm{K} 2=0,04 \%$,, $\mathrm{K} 3=0,08 \%$, $\mathrm{K} 4=0,16 \%$ dan $\mathrm{K} 5=0,32 \%$ dengan 5 perlakuan dan 3 kali ulangan. Sampel penelitian adalah larva nyamuk Anopheles instar III.

\section{Pembuatan Ekstrak Biji Pangi}

a. Daging biji pangi yang berwarna putih ditimbang sebanyak 150 gram kemudian di cuci dengan air sampai bersih dan diangin-anginkan selama 15 menit.

b. Daging biji pangi dimasukan ke dalam blender, dihaluskan selama 5 menit.

c. Daging biji pangi yang sudah halus dicampurkan dengan $150 \mathrm{ml}$ aquades (konsentrasi 100\%, b/v) dikocok menggunakan shaker selama 30 menit (Yuningsih, 2008).

d. Larutan ekstrak yang diperoleh disaring dengan 4 lapis kain kasa untuk memisahkan filtratnya sebagai ekstrak biji pangi (EBP).

e. Filtrat ekstrak biji picung (EBP) di masukan dalam labu erlenmeyer.

f. Mulut labu erlenmeyer di sumbat dengan kapas dan aluminium foil

\section{Tahap Penelitian}

a. Ditentukan konsentrasi ekstrak biji pangi yang akan digunakan. ekstrak biji pangi yang digunakan adalah $\mathrm{K} 1$ kontrol, K2 0,04\%, K3 0,08\%,K4 0,16\%, dan K5 0,32\% (Wijaya, 2009).

b. Larutan uji masing-masing konsentrasi dimasukan dalam wadah terpisah

c. Larva nyamuk Anopheles instar III sebanyak 25 ekor diambil menggunakan pipet dan masukan kedalam masing-masing konsentrasi ekstrak yang sudah disiapkan.

d. Larva dibiarkan kontak dengan larutan uji selama 24 jam

e. Perlakuan diulang sebanyak 3 kali

f. Larva diamati selama 24 jam, setelah itu diberi rangsangan gerakan dengan menggunakan lidi

g. Mortalitas larva pada kelompok perlakuan dibandingkan dengan kontrol yaitu larva Anopheles yang dimasukan dalam aquades.

Pengamatan dilakukan terhadap mortalitas larva nyamuk Anopheles setelah pendedahan selama 24 jam. Mortalitas larva yang dihitung dengan menggunakan rumus:

$$
M=\frac{a}{b} \times 100 \%
$$

$$
\begin{aligned}
& \text { Ket: } M=\text { Persentase mortalitas, larva nyamuk } \\
& a=\text { Jumlah larva nyamulk yang mati } \\
& b=J u m l a h \text { larva nxamulk yang digunakan sebagai }
\end{aligned}
$$

Selama penelitian pada semua
kelompok uji tidak diberikan bahan
makanan (Cavalcanti Larva yang mat merupakan larva yang tidak menunjukan tanda-tanda kehidupan, yaitu tenggelam ke dasar, tidak bergerak, meningalkan larva lain yang dapat bergerak dengan jelas dan tidak berespon terhadap rangsangan gerakan air maupun disentuh dengan lidi (Wijaya, 2009).

Setelah semua data didapatkan, selanjutnya dilakukan pengolahan dan analisis data menggunakan software SPSS 16.0 yaitu Uji One Way ANOVA untuk mengetahui pengaruh ekstrak biji pangi terhadap mortalitas larva nyamuk antar kelompok uji, Analisis Probit untuk menentukan efek mortalitas ekstrak ekstrak biji pangi (Pangium edule Reinw.) terhadap larva nyamuk Anopheles yang dinyatakan dengan Lethal Concetration (LC) pada taraf 
$\mathrm{LC}_{50}$, Uji Duncan untuk mengetahui beda pengaruh antara setiap level konsentrasi, Uji Corellation Pearson untuk mengetahui hubungan antara konsentrasi ekstrak biji pangi (Pangium edule Reinw.) dan larva nyamuk Anopheles.

\section{HASIL DAN PEMBAHASAN Hasil Penelitian}

Tingkat kematian larva nyamuk Anopheles dengan waktu pendedahan selama 24 jam, hasilnya dapat dilihat pada tabel berikut.

Tabel 1. Mortalitas Larva Nyamuk Anopheles selama 24 Jam.

\begin{tabular}{cccccc}
\hline Kelompok $/$ & \multicolumn{3}{c}{ Ulangan } & Jumlah & $\begin{array}{c}\text { Mortalitas } \\
(\%)\end{array}$ \\
\cline { 2 - 4 } Konsentrasi & 1 & 2 & 3 & & 0 \\
\hline K1 Kontrol & 0 & 0 & 0 & 0 & 46.64 \\
K2 $(0,04 \%)$ & 11 & 12 & 12 & 35 & 60 \\
K3 $(0,08 \%)$ & 14 & 16 & 15 & 45 & 72 \\
K4 $(0,16 \%)$ & 18 & 19 & 17 & 54 & 98,66 \\
K5 $(0,32 \%)$ & 24 & 25 & 25 & 74 & \\
\hline
\end{tabular}

Berdasarkan tabel 1, terlihat adanya perbedaan jumlah larva yang mati antar kelompok perlakuan. Untuk K1 atau kontrol persentase kematian sebesar $0 \%$ atau pada semua replikasi tidak ditemukan adanya larva yang mati. Hal ini membuktikan bahwa selama masa uji kelembapan udara dan suhu pada laboratorium masih dalam keadaan ideal untuk pertumbuhan larva, sehingga dapat dikatakan bahwa secara umum tidak berpengaruh terhadap mortalitas larva nyamuk Anopheles. Selanjutnya, perlakuan konsentrasi terendah K2 0,04\% mampu membunuh $46,64 \%$ dari jumlah nyamuk yang diujikan. Pada perlakuan $\mathrm{K} 3$ 0,08\% dan K4 0,16\% terjadi peningkatan mortalitas dengan mencapai $60 \%$ dan $72 \%$. Sedangkan untuk perlakuan konsentrasi K5 0,32\% mortalitas sangat baik dengan persentase mortalitas mencapai hampir $100 \%$ larva nyamuk Anopheles yang diujikan. kenaikan konsentrasi juga diikuti dengan jumlah kematian larva sampai konsentrasi tertentu dapat dilihat pada Gambar 1.

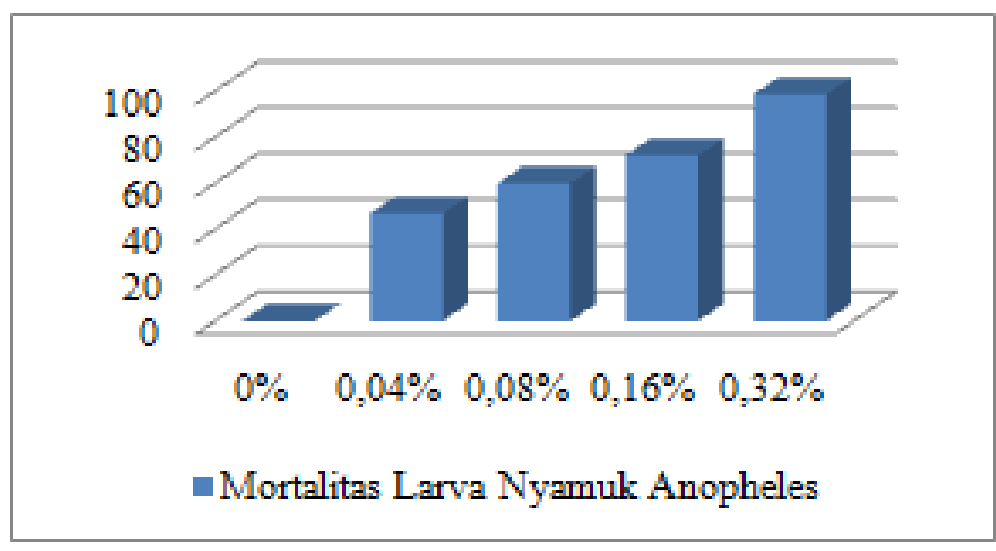

\section{Gambar 1. Rata-Rata Mortalitas Larva Nyamuk Anopheles Selama 24 Jam Menggunakan Ekstrak Biji Pangi (Pangium edule Reinw.)}

Untuk mengetahui ekstrak biji Pangi (Pangium edule Reinw.) efektiv terhadap mortalitas larva nyamuk Anopheles digunakan uji parametrik One Way ANOVA dan Analisis Probit $\mathrm{LC}_{50}$. 
Tabel 3. Ekstrak biji Pangi (Pangium edule Reinw.) efektiv terhadap mortalitas larva nyamuk Anopheles.

\begin{tabular}{lrrrrr}
\hline MortalitasLarva & Jumlah kuadrat & \multicolumn{1}{c}{ Derajat bebas } & Kuadrat tengah & F hit & \multicolumn{1}{c}{ Sig. } \\
\hline Antar grup & 996.400 & 4 & 249.100 & 467.063 & .000 \\
dalam grup & 5.333 & 10 & .533 & & \\
Total & 1001.733 & 14 & & & \\
\hline
\end{tabular}

Terlihat bahwa nilai $F_{\text {hitung }}$ adalah terhadap mortalitas larva nyamuk 467.063 dengan nilai Sig. 0,000 dengan signifikansi $0,000<0,05$, Hal ini Anopheles. Selanjutnya dilakukan analisis probit taraf $\mathrm{LC}_{50}$ untuk mengetahui menunjukkan ekstrak biji pangi efektiv konsentrasi yang efektiv sebagai larvasida.

Tabel 4. Nilai LC ${ }_{50}$ ekstrak biji pangi (Pangium edule Reinw.) Terhadap Mortalitas Larva Nyamuk Anopheles.

\begin{tabular}{ccccc}
\hline & \multicolumn{4}{c}{ Tingkat Kepercayaan Konsentrasi 95\% } \\
\cline { 2 - 5 } Probit & probabilitas & Estimasi & $\begin{array}{c}\text { Batas } \\
\text { bawah }\end{array}$ & $\begin{array}{c}\text { Batas } \\
\text { atas }\end{array}$ \\
0.5 & .053 & .038 & .066 \\
\hline
\end{tabular}

Menurut WHO dalam Cania (2013), konsentrasi dianggap efektiv apabila dapat menyebabkan kematian larva uji antara 10$95 \%$ yang nantinya digunakan untuk mencari Lethal Concentration. Nilai LC yang dipilih dalam penelitian ini adalah $\mathrm{LC}_{50}$. Hal ini karena untuk peneltian uji daya bunuh suatu insektisida, tingkat konsentrasi insektisida dianggap memiliki daya bunuh baik serta tidak berbahaya bagi lingkungan apabila mencapai LC $_{50}$. Nilai LC dibawah $\mathrm{LC}_{50}$ dikategorikan memiliki daya bunuh rendah, dan nilai LC diatas $\mathrm{LC}_{50}$ dikategorikan memiliki daya bunuh efektif.
Tetapi untuk insektisida yang mampu mencapai LC diatas $\mathrm{LC}_{50}$ memerlukan pengujian untuk mengetahui tingkat keamanannya terhadap kelestarian lingkungan hidup. Hasil analisis probit nilai $\mathrm{LC}_{50}$ didapatkan pada konsentrasi sebesar 0,053\%. Dengan demikian, dapat dikatakan bahwa ekstrak biji pangi (Pangium edule Reinw.) dengan konsentrasi 0,053\% efektiv dan berpotensi sebagai larvasida alami karena dapat membasmi 50\% larva uji. Selanjutnya dilakukan uji Duncan pada mortalitas larva nyamuk Anopheles.

Tabel 5. Beda Pengaruh Konsentrasi Ekstrak Biji Pangi (Pangium Edule Reinw.) terhadap Mortalitas Larva Nyamuk Anopheles.

\begin{tabular}{ccccccc}
\hline Konsentrasi $\%$ & Mortalitas Rerata & \multicolumn{3}{c}{ Notasi } & \\
\hline K1 kontrol & 0.00 & a & & & \\
K2 0.04 & 11.67 & & b & & \\
K3 0.08 & 15.00 & & & c & & \\
K4 0.16 & 18.00 & & & & d & \\
K5 0.32 & 24.67 & & & & e \\
\hline
\end{tabular}

Dari hasil uji Duncan yang diperlihatkan pada Tabel 4.5, menunjukan bahwa terdapat perbedaan rata-rata pada setiap pada level konsentrasi yang digunakan dalam pengujian mortalitas larva nyamuk Anopheles. Pada K1 Kontrol sebesar 0.00 ditandai dengan notasi (a) berbeda dengan
$\mathrm{K} 2, \mathrm{~K} 3, \mathrm{~K} 4$ dan $\mathrm{K} 5$, selanjutnya $\mathrm{K} 2 \quad 0.04 \%$ sebesar 11,67 ditandai dengan notasi (b) berbeda dengan $\mathrm{K} 1, \mathrm{~K} 3, \mathrm{~K} 4$ dan $\mathrm{K} 5$, selanjutya untuk K3 $0.08 \%$ sebesar 15.00 notasi (c) menunjukan perbedaan terhadap $\mathrm{K} 1, \mathrm{~K} 2$, $\mathrm{k} 4$ dan $\mathrm{K} 5$, hal yang sama terjadi pada K4 $0.16 \%$ sebesar 18.00 ditandai 
dengan notasi (d) terhadap K1, K2, K3 dan $\mathrm{K} 5$, dan $\mathrm{K} 50.32 \%$ sebesar 24,67 ditandai dengan notasi (e) terhadap $\mathrm{K} 1, \mathrm{~K} 2, \mathrm{~K} 3$ dan K4. Adanya perbedaan notasi untuk setiap level konsentrasi menunjukan perbedaan yang sangat nyata dengan taraf kepercayaan 95\% $(\alpha=0,05)$ yang diuji kepekaannya terhadap mortalitas larva nyamuk Anopheles. Dari hasil tersebut memperlihatkan bahwa konsentrasi $0.04 \%$ adalah konsentrasi yang memiliki efek toksik terendah, sedangkan konsentrasi $0.032 \%$ adalah konsentrasi dengan efek toksik yang paling tinggi terhadap mortalitas larva nyamuk Anopheles sedangkan kontrol tidak memiliki efek toksik untuk membunuh larva nyamuk Anopheles.

Tabel 6. Hubungan Ekstrak Biji Pangi (Pangium edule Reinw.) Terhadap Mortalitas Larva Nyamuk Anopheles.

\begin{tabular}{l|l|r|r}
\hline \multicolumn{2}{l|}{} & Konsentrasi & MortalitasLarva \\
\hline Konsentrasi & Pearson Correlation & 1 & $.891^{* *}$ \\
& Sig. & 15 & .000 \\
& N & 15 & 15 \\
MortalitasLarva & Pearson Correlation & $.891^{* *}$ & 1 \\
& Sig. & .000 & \\
& $\mathrm{~N}$ & 15 & 15 \\
\hline
\end{tabular}

Hasil uji Correlation Pearson pada tabel 6 untuk mengetahui hubungan antara konsentrasi ekstrak biji pangi dengan tingkat mortalitas larva nilainya adalah 0,891. Berdasarkan Sugiyono (2002) bahwa interval koefisien korelasi 0,00-0,199 tingkat hubungan sangat rendah, 0,20-0,399 tingkat hubungan rendah, 0,40-0,599 tingkat hubungan sedang, 0,60-0,799 tingkat hubungan kuat dan koefisien korelasi 0,800-1.00 tingkat hubungannya sangat kuat. Nilai koefisien korelasi pada penelitian ini adalah 0,891 berada dalam interval 0,800-1,00 yang berarti terdapat hubungan yang kuat antara konsentrasi masing-masing ekstrak biji pangi (Pangium edule Reinw.) dengan mortalitas larva nyamuk Anopheles.

Hasil pengamatan gejala yang teramati dalam penelitian ini untuk semua perlakuan nyamuk Anopheles yang mengalami kontak dengan ekstrak yaitu larva mulai meniggalkan koloninya, gerakannya mulai melambat, larva berada pada dasar wadah, saat diberi rangsangan gerakan menggunakan lidi larva tidak menunjukan respon dan larva mengalami kematian. Mekanisme kematian larva diperkirakan berhubungan dengan senyawa alkaloid dan saponin pada biji pangi yang dapat mengganggu sistem saraf dan merusak membran sel larva. Ekstrak biji pangi masuk ke dalam tubuh melalui mulut larva. Ekstrak biji pangi berupa alkaloid yang masuk kedalam tubuh larva akan mengganggu metabolisme. Metabolisme yang terganggu menyebabkan larva kekurangan energi untuk hidupnya, hal tersebut ditandai dengan larva yang tidak mampu berenang kepermukaan, kejang dan mati. Ekstrak biji pagi yang mengandung alkaloid mengakibatkan kerusakan sel. Larva mati dikarenakan racun berupa alkaloid yang masuk akan menghambat metabolisme sel dan menghambat kerja enzim asetilkolinesterase. Asetilkolin yang dibentuk oleh sistem saraf pusat berfungsi untuk menghantarkan impuls dari sel saraf ke sel otot. Setelah impuls dihantarkan, prosesnya dihentikan oleh enzim asetilkolinesterase yang memecah asetilkolin menjadi asetil ko $\mathrm{A}$ dan kolin. Adanya senyawa alkaloid akan menghambat bekerjanya enzim ini sehingga terjadi penumpukan asetilkolin yang akan menyebabkan terjadinya kekacauan pada sistem penghantaran impuls ke otot yang dapat berakibat otot kejang, terjadi kelumpuhan (paralysis) dan berakhir ke kematian (Hadi et al., 2009). Hal ini sesuai dengan pendapat Jumar (2000), bahwa keracunan pada serangga ditandai dengan terjadinya gangguan pada sistem saraf pusat yang mengakibatkan terjadinya kerusakan saraf dan menyampaikan hasil integrasi ke otot yang merupakan reaksi terhadap racun yang masuk kedalam tubuh, sehingga mengakibatkan kematian. 
Selain kandungan alkaloid, ekstrak biji pangi mengandung senyawa saponin. Senyawa aktif saponin mempunyai efek menurunkan tegangan permukaan sehingga merusak membran sel, menginaktifkan enzim sel dan merusak protein sel. Saponin dapat berikatan dengan fosfolipid yang menyusun membran sel sehingga mengganggu permeabilitas membran sel (Widodo, 2005). Dalam penelitian ini ekstrak biji pangi yang mengandung saponon masuk kedalam tubuh larva nyamuk Anopheles melalui mulut larva. Selanjutnya mengganggu aktivitas membran sel larva. Permeabilitas membran turun maka mengakibatkan senyawa-senyawa toksik masuk sehingga menggangu proses metabolisme larva, pembentukan ATP juga terhambat sehingga larva kekurangan energi dan menyebabkan kematian. Selain itu, Saponin berfungsi sebagai racun perut atau racun pencernaan. Hal ini sesuai dengan Dinata (2009), yang mengemukakan bahwa cara kerja dari saponin adalah menurunkan tegangan permukaan selaput mukosa traktus digestivus larva sehingga menjadi korosif. Saponin juga dapat menyebabkan kerusakan pada jaringan epitelium pada usus engah larva sehingga gagal mengabsorbsi sari-sari makanan yang seharusnya diedarkan melalui haemolimfe, terhambatnya proses absorpsi sari-sari makan mengakibatkan proses pertumbuhan larva terhambat dan akhirnya menyebabkan kematian pada larva Dalam hal ini alkaloid dan saponin bersifat toksik bagi larva nyamuk Anopheles.

Peningkatan mortalitas larva nyamuk Anopheles disebabkan karena peningkatan konsentrasi ekstrak. Ini mengindikasikan bahwa masing-masing konsentrasi memiliki kadar toksit yang berbeda. Hal ini dibuktikan dengan rendahnya konsentrasi ekstrak memiliki kadar toksit yang rendah sehingga menyebabkan mortalitas larva yang rendah pula. Sebaliknya, semakin tinggi konsentrasi ekstrak akan memiliki kadar toksit yang tinggi sehingga menyebabkan mortalitas larva semakin tinggi pula. Hal ini sejalan dengan yang diungkapkan oleh Watuguly (2003), bahwa faktor yang paling menentukan potensi bahaya atau amannya suatu senyawa adalah hubungan antara kadar zat kimia dengan efek yang ditimbulkannya. Selain itu, interaksi suatu bahan racun dengan sistem hayati berhubungan langsung dengan banyaknya kandungan bahan racun. Dengan demikian dapat diasumsikan bahwa mortalitas larva uji disebabkan karena kandungan senyawa kimia dalam ekstrak biji pangi (Pangium edule Reinw.).

Pengendalian vektor penyakit malaria merupakan salah satu upaya yang dilakukan untuk mengurangi terjadinya angka kesakitan malaria. Berbagai upaya telah dilakukan oleh pemerintah untuk mengendalikan penyakit Malaria yaitu Pemantauan Jentik Rutin (PJR), Pemantauan Jentik Berkala (PJB), Pemberantasan Sarang Nyamuk (PSN) melalui 3M plus (Menguras, Menutup, dan Mengubur), plus menabur larvasida, penyebaran ikan pada tempat penampungan air, serta kegiatan-kegiatan lainnya yang dapat mencegah atau memberantas nyamuk Anopheles berkembang biak. Salah satu yang dilakukan juga adalah penggunaan insektisida dalam membunuh nyamuk pada stadium dewasa. Penggunaan insektisida sintetis yang berlebihan dan dalam jangka waktu panjang dapat menimbulkan beberapa kerugian seperti nyamuk menjadi resisten, terjadinya keracunan pada manusia dan hewan ternak, serta polusi lingkungan, maka perlu suatu usaha untuk mendapatkan alternatif yang lebih efektiv. Salah satu solusi yang baik untuk pencegahan yaitu pencegahan pada stadium larva. Dengan dilakukannya pengendalian stadium larva perkembangan dan penyebaran malaria melalui nyamuk Anopheles serta Angka kesakitan malaria dapat ditekan jumlahnya. Pengendaliannya dapat dilakukan dengan menggunakan insektisida atau larvasida dengan bahan alami dan ramah lingkungan. Sesuai hasil penelitian yang telah dilakukan menunjukan bahwa pemberian ekstrak biji pangi berpengaruh pada tingkat mortalitas larva nyamuk Anopheles. Hal ini menunjukan bahwa biji pangi adalah salah satu tanaman yang baik dan dapat dimanfaatkan sebagai larvasida alami dan juga didukung dengan kandungan senyawa alkaloid dan sianida. Biji pangi sebagai larvasida alami merupakan salah satu alternatif yang baik digunakan sebagai larvasida alami untuk 
mengganti larvasida kimia yang banyak menimbulkan kerugian antara lain menyebabkan pencemaran lingkungan dan resistensi terhadap serangga.

\section{KESIMPULAN DAN SARAN}

Berdasarkan hasil penelitian mengenai efektivitas ekstrak biji pangi (Pangium edule Reinw) terhadap mortalitas larva nyamuk Anopheles dapat disimpulkan bahwa ekstrak biji pangi (Pangium edule Reinw) berpengaruh terhadap mortalitas larva nyamuk Anopheles dengan nilai $\mathrm{LC}_{50}$ ekstrak biji pangi (Pangium edule Reinw) dalam 24 jam adalah 0,053\%, setiap konsentrasi ekstrak biji pangi (Pangium edule Reinw) memiliki beda pengaruh terhadap mortalitas larva nyamuk Anopheles dalam 24 jam waktu pengamatan dan terdapat hubungan antara berbagai konsentrasi biji pangi (Pangium edule Reinw) dengan mortalitas larva nyamuk Anopheles dengan nilai $(p)=0,000$ dan tingkat hubungannya sangat kuat dengan nilai pearson corellationnya 0,891 .

Disarankan Biji pangi dapat digunakan sebagai alternatif pengendalian alami (larvasida yang aman) bagi vektor penyakit khususnya larva nyamuk Anopheles dan membuat produk pembasmi nyamuk menggunakan biji Pangi.

\section{DAFTAR PUSTAKA}

Dinata, L. P. 2009 Formulasi Tablet Ekstrak Herba Tapak Dara (Catharantus roseus (L) G. Don) dengan Bahan Pengikat Gelatin dan Gom Arab

Dinas Kesehatan Provinsi Maluku, 2013. (online) http://www.depkes.go.id/ resources/download/profil/PROFIL KE S PROVINSI 2012/30 Profil Kes.Prov .Maluku 2012.pdf.

Diakses tanggal 31 November 2015.

Erni, R.A.H. 2006. Picung, pengawet alami ikan segar. (online) Website:www.nuraulia.multiply.com. Diakses tanggal 20 Juni 2015.

Hadi, H. Mochamad., U. Tarwotjo., R Rahadian. 2009. Biologi Insekta Entomologi. Yogyakarta: Graha Ilmu.

Heriyanto, N.M., E. Subandiono. 2008. Ekologi Tanaman Kluwek/Pakem
(Pangium edule Reinw.) di Taman Nasional Meru Betiri Jawa Timur. Buletin Plasma Nutfah 14(1):33-42

Hoe, V.B., K.A.Siong. 2002 The Nutritional Value of Indigenous Friuts and Vegetables in Sarawak. Asia Pasific Journal of Clinical Nutrition. Vol 8 Issue 1.pp.24-31.

Jumar, 2000. Etimologi Serangga. PT. Rineka Cipta, Jakarta

Pagaya, J, M Nindatu, F Ririhena. 2005. Analisa Kepadatan Larva dan Survei Tempat perindukan Nyamuk Aedes (Diptera: Culicidae) di Dusun waimahu Kecamatan Nusaniwe, Kota Ambon. Majalah Kedokteran Tropis Indonesia, Ambon.

Sanaky. 2014. Hubungan dan Peta Sebaran Malaria di Kota Ambon. Skripsi. Fakultas Kesehatan Masyarakat, Universitas Hasanuddin, Makassar.

Sugiyono. 2002. Statistika untuk Penelitian. Bandung: Alfabeta

Tennyson S, Ravindran KJ, Arivoli S. (2012) Screening of twenty five plant extracts for larvicidal activity against Culex quinquefasciatus Say (Diptera: Culicidae). Asian Pac J Trop Biomed. S1130-S1134

Warintek. 2006. Klasifikasi. http://warintek. progressio.or.id/. Diakses 1 Juli 2015

Watuguly, T. 2003. Uji Toksisitas Bioinsektisida Ekstrak Biji Mahkota Dewa (Phaleria papuana Warb.) terhadap Mortalitas Nyamuk Aedes agypti Linn di Laboratorium. Universitas Airlangga. Surabaya.

Widodo, W. 2005. Tanaman Beracun Dalam Kehidupan Ternak. Malang: Universitas Muhamadiyah Malang.

Wijaya, L.A. 2009. Daya Bunuh Ekstrak Biji Kecubung (Datura Metel) terhadap Larva Aedes aegypti. Skripsi. Surakarta; Fakultas Kedokteran Universitas Sebelas Maret, hal 7.

Yuningsih. 2008. Kandungan dan Stabilitas Sianida Dalam Tanaman Picung (Pangium edule Reinw.) Serta Pemanfaatannya. Jurnal Balai Besar Penelitian Veteriner.http://balittro. litbang.deptan.go.id/ind/images/stories/ edsus/vol20n02/4stabilitas.pdf. diakses tanggal 11 Juli 2015. 